\title{
Literature and Human Resilience in the Time of Crises Like Coronavirus Pandemics
}

\author{
IJCRR \\ Section: Healthcare \\ ISI Impact Factor \\ (2020-21): 1.899 \\ IC Value (2020): 91.47 \\ $\operatorname{SJIF}(2020)=7.893$

\section{Arvind M. Nawale} \\ Associate Professor and Head, Department of English, Shivaji Mahavidyalaya, Udgir (Maharashtra) India. \\ (c) (i) (9) \\ Copyright@IJCRR
}

\section{ABSTRACT}

The COVID-19 pandemic has compelled us to rethink our way of life. In such pandemics or epidemics or other sorts of calamities and crises, the literature provides artistic relief and comfort in such agonies. In addition, it makes us aware of the universality of death and the necessary precautions for our recovery and survival. To explore how literature offers a worth reading to console our hearts and foster resilience in pandemic crises like COVID-19. Studying, reviewing and analyzing relevant literary texts to reach conclusion. Literature gives us an opportunity to study texts written on pandemics and how such events have historically been projected and how they have served as guiding forces. It helps people by inspiring them to act fairly. In such pandemic situations, it is a worthwhile read to soothe our hearts. Reading literature during the period of crises encourages us in driving away isolation, retaining sanity, fostering resilience and above all, instill the courage to face and hope.

Key Words: Pandemic literature, Epidemics, Covid-19, Coronavirus Disease, Literature and Calamities

\section{INTRODUCTION}

The Coronavirus infection initially appeared in Wuhan, China, at the end of 2020. Because of its fast worldwide spread, the World Health Organization (WHO) declared it as a "pandemic"1 on March 11, 2020. In India, "the first COVID-19 positive case was disclosed in Kerala" ${ }^{2}$ on $30^{\text {th }}$ January 2020, with a student who travelled from Wuhan University in China to Kerala. The number of COVID-19 cases in India is currently skyrocketing. According to World Corona Meter numbers as on $10^{\text {th }}$ Nov. 2021, India had documented 34,386,786 COVID-19 infections across the country, resulting in 461,827 fatalities, compared to $251,560,303$ confirmed cases and 5,079,851 deaths globally. ${ }^{3}$ Almost all governments throughout the world have set asingle objective to cope up with the spread of this exceedingly infectious disease by lockdown, social/physical distancing, the use of face masks, 'Work from Home', the avoidance of face-toface interactions, vaccination and so on.

The COVID-19 outbreak triggered a global health crisis that endangers our financial stability, economy, employment, security and social well-being. The shutdown has put people in a deplorable, unsettling situation. Social distance and physi- cal isolation cause acute stress disorders, irritability, anxiety, depression, psychological distress and other mental health effects. Citizens from almost every part of the world are forced to go home confined.

\section{LITERATURE AND HUMAN RESILIENCE IN THE TIME OF CRISES:}

Is this the first pandemic that the world is facing? Obviously, the answer is no. Since its beginning, the earth has undergone through several epidemics, pandemics and time of crises like Black Death (also called as the Plague), the deadliest pandemic of influenza ever seen in 1918 (also known as Spanish flu), the Smallpox outbreak, Swine flu, AIDS, Ebola or Zika virus, disasters like the two World Wars or some other social/ global crisis and so on.

Crises like this are not new to human nature, there is also possibility to confront with anything like this again in our future too. So, what's going to help us get through this? And the answer is simple- resilience. Resilience is the capacity to recover quickly from adversities, worries and hard time. It is an ability to adjust easily to misfortunes and to recover

\section{Corresponding Author:}

Dr. Arvind M. Nawale, Associate Professor and Head, Dep of English, Shivaji Mahavidyalaya, Udgir (Maharashtra) India. Email: amnawale@gmail.com

ISSN: 2231-2196 (Print)

ISSN: 0975-5241 (Online)

Received: 24.10 .2021

Revised: 18.11 .2021

Accepted: 15.12 .2021

Published: 15.02 .2022 
readily from illness, depression, calamities and crises. It is an aptitude to cope or adapt when confronted with adverse life events. One can build resilience by cultivating character, coping with stress, treating problems as challenges; learning to accept things that you can't change and we can attain all these things only by reading literature.

Let's see how the literature has responded, how the literature can play a role in times of such calamities. How literature is helpful to mankind in such emergencies?

\section{DISCUSSION}

Whether it was epidemics, pandemics or other sorts of crises, the literature never took the back seat. Instead, literature raises the spirit and provides artistic relief and comfort in such lock-down or house arrest and quarantine agonies. In addition, it makes us aware of the universality of death and the necessary precautions for our recovery and survival. As stated by Avijit Ghosh, "Literature provides us deepest and insightful record of events during pandemics and tries to provide consolation in times of need". ${ }^{4}$ Catharsis has always been one of the functions of literature, whether Indian or Western - a way of coping with deep emotions, a manner of purgation, a way of healing. In such times, literature has a vital role in moulding our emotions, bringing solace and consolation.

Literature gives us an opportunity to study texts written on pandemics and how such events have historically been projected by authors and how they have served as guiding force and can now be accepted to face pandemic like COVID-19. Some of such prominent literary texts like Homer's 'Iliad', Giovanni Boccaccio's 'Decameron', Albert Camus' 'The Plague', Stephen King's 'The Stand', Ling Ma's 'Severance'; Randy Shilts' 'And the Band Played on: Politics, People, and the AIDS Epidemic'; Steven John's 'The Ghost Map'; Gina Kolata's 'Flu: The Story of the Great Influenza Pandemic of 1918 and the Search for the Virus That Caused It'; Sonia Shah's 'The Fever: How Malaria Has Ruled Humankind for 500,000 Years', Richard Preston's 'The Hot Zone: The Terrifying True Story of the Origins of the Ebola Virus and so on are worth to mention here which provide hopes and ways to deal with such disasters.

'The Decameron' is a collection of 100 allegorical tales written by Giovanni Boccaccio around the year 1353. It accounts the stories of ten young Florentines who have fled from the Black Plague to reside in Naples villa. It prominently narrates the struggle between life and death in the context of the Black Plague that fell upon Florence in 1348.

Edgar Allan Poe's short story "The Masque of the Red Death" (1842) relates a horrifying tale of a fictional plaguea disease known as the Red Death sweeping through the land which causes its victims to die quickly within 30 minutes after getting infected where even the prince, Prospero brings together his 1000 special guests and seals the gates of his palace in order to make himself and his 1000 friends home quarantined and get protected from the plague. But at last, the plague reaches in the castle and Prince Prospero and all of his 1000 guests die of the Red Death. Poe describes it as: "And now was acknowledged the presence of the Red Death. He had come like a thief in the night. And one by one dropped the revelers in the blood-bedewed halls of their revel and died each in the despairing posture of his fall. And the life of the ebony clock went out with that of the last of the gay. And the flames of the tripods expired. And Darkness and Decay and the Red Death held illimitable dominion over all". ${ }^{.}$Prince Prospero and his guests thought they had found a way to escape from the plague, but they too were infected and found dead.

The current situation in COVID-19 is similar to the scenario written by Nobel laureate Albert Camus in his short novel 'The Plague' (1947) in which he describes the 19th century Plague outburst, which led to the alienation and isolation in the human beings succeeding their panic condition. Camus describes: "How should they have given a thought to anything like the plague, which rules out any future, cancel journeys and silences the exchange of views. They fancied themselves free, and no one will ever be free so long as there are pestilences. ${ }^{6}$ Similar sort of terror and fearful characteristics can be traced in COVID-19. Camus' exile and isolation in his novel 'The Plague' is close to the COVID-19 emergency quarantine system. For today's COVID-19 affected humanity, this novel is like a mental and psychological antidote. It has a new meaning, urgency and lessons to learn. According to the World Economic Forum COVID Action Platform, Albert Camus' novel 'The Plague" is one of " 5 books to read for context on the coronavirus outbreak". The World Economic Forum further states: "It was written more than 70 years ago, but Albert Camus' celebrated classic La Peste (The Plague) is speaking to us as loudly as ever. The book, which tells of the spread of a plague in a North African town and the human response to death, has seen a major uptick in sales since the outbreak of the coronavirus". ${ }^{7}$

'The Great Influenza: The Story of the Deadliest Plague in History' (2004) by John M. Barry is also a worth book to mention here. When American President George Bush read this book, he acknowledged that it helped him to assess the federal government's future policy on pandemics and said, "If we wait for a pandemic to appear, it will be too late to prepare". ${ }^{8}$ Even Bill Gates agreed that "This book taught me a lot about the Spanish Flu".

Such literary texts look compassionately at every person and go deeper than statistics or historical records. It does not 
counter modern science but serves as a source of comfort and means of expressing our common humanistic concerns.

Is it a reality or assumptions is the matter of investigation and debate but according to the Greek myths and literature, such epidemics are caused as the punishment by the Almighty God for some sins committed by the people on the Earth. For example, In Sophocles' 'Oedipus, the King', the king unknowingly kills his father and marries with his own mother. In this context, it is believed that the dreadful pestilence which was appeared in the form of the plague was due to the anger of God over the misdeed of man, Oedipus the king. Even today, it is often believed that men's misdeeds lead to this kind of epidemics. Isn't COVID-19 a global tragedy of human misdeeds? Was it not the outcome of the misdeed of men in the Wuhan Wet market in China, where many wild animals were killed, including dogs, snakes, rats and bats? Is this, not the result of our unfaithfulness to God, animals, and the environment? Literature often predicts such abuses and their consequences. Everyone recognizes the importance of literature which gives lessons in restoring shattered trust and losing the core values of life in a disaster.

Literature is, therefore, a universal tool for building life during such a pandemic crisis. It helps people by inspiring them to act fairly in their lives.

'A Journal of the Plague Year' (1722) by Daniel Defoe serves as a practical handbook of 'things to be done' before and during the deadly outbreak, thereby acting as an alarm. Mary Shelley's pandemic novel, 'The Last Man'(1826) elucidates the narratives of life-saving message. Jack London's post-apocalyptic book, Scarlet Plague (1912) is a robust study of today like pandemic eruptions. Max Brook's 'World War Z' (2006) teaches how to resist the plague and how to uphold the spirit of the age as well as the spirit of body and mind. Colin Diyen Ayeah in 'The Earth in Peril'(2010) aptly narrates pandemic culture for healing and transformation of humanity. Such narratives have the power to preserve and rebuild the universe as it falls apart due to the deadly diseases.

Not only pandemic literature but other pieces of literature, too, offer a worth reading to console our hearts in such pandemic crises.

'The Second Coming', a well-known poem by W.B. Yeats is worth to be remembered in such time of chaos and uncertainty. He wrote the poem in the year 1919, after witnessing the Irish Civil War of 1916 and the end of the First World War, giving voice to the hopelessness for the future of humankind.

"Turning and turning in the widening gyre

The falcon cannot hear the falconer;

Things fall apart; the centre cannot hold;

Mere anarchy is loosed upon the world". ${ }^{10}$
The metaphor of falcon and falconer stands for nature and humanity therein where Nature found no longer remain connected to the human world.

"Ode to the West Wind" by P. B. Shelly which talks about power, human limitations and the natural world is famous for its prophetic message of hope.

"The trumpet of a prophecy! O Wind,

If Winter comes, can Spring be far behind?"'11

The optimistic message in last line 'If Winter comes, can Spring be far behind?' is inspiring in such pandemonium situation.

Reading the 'Daffodils' by William Wordsworth, the 'Ode to Autumn' by John Keats, or the sonnets by William Shakespeare on Fair Youth and Dark Lady or the sonnets by Philip Sidney on Astrophel and Stella, bring pure pleasure, something healing that any lover of poetry would agree with. The beauty of such works promotes peace of mind and the spirit delights with its artistic creativity. While one is in home quarantine due to the Covid-19 pandemic, one can escape to strange and unknown realms through the descriptions of writers- from the Moors of Charlotte Bronte to Coleridge's Xanadu, from Thomas Hardy's Wessex novels toR. K. Narayan's Malgudi world, we can meet people, interact with them and go through situations which would provide relief to us! 'The Alchemist' by Paulo Coelho, 'The Old Man and the Sea' by Earnest Hemingway and so many are too good to read and get inspired to face the crises.

Especially at the present time of crises, reading literature is even more imperative, considering our mental well-being. Some of the key roles of literature are to provide readers with a variety of opportunities to explore ease, motivation, humour, intelligence, inspiration, and imagination. In addition, literature sends us messages, whether in prose or poetry, to help make our lives happy and hopeful.

For example, Antony Chekov, in his short story 'The Bet' (1889) depicts two men, a banker and a lawyer who make a bet on the idea of the death penalty and life imprisonment. The banker is promising $\$ 2$ million for a 15 -year prison term for the defendant. It's also interesting to hear how the prosecutor spends his time in lockup. The lawyer started reading books, after doing other things of interest for many years. These books are of different types. At the end of the story, through these books, the lawyer discovers that he has met plants, creatures, places and people. He has experienced all feelings, emotions, comfort through these stories and has gained knowledge of many things including the purpose of life. He realized that it is his achievement and he no more needs money for which he spent 15 years in solitary confinement. He breaks the bet a few hours before the last day by 
leaving a note of what he has gained. This teaches us how the reading of books is important in life.

O Henry's short story 'The Last Leaf' depicts Johnsy, a delicate, serious young woman affected with pneumonia. She is worried about her condition and has lost all hopes of recovery. She starts watching the ivy plant on the wall outside her door. She compares her illness with the falling leaves of the plant. She thinks she is going to die when this ivy plant would lose its last leaf. Her friend who was much concerned of her situation gets the same leaf painted on the wall with the help of an artist. Johnsy recovers as that last leaf remain for a long time. Her positive energy helps her to cure.

Robert Frost's poem 'Stopping the Woods on a Snowy Evening' (1923) portrays a traveler who pauses to watch the snowfall all around him and got attracted to the deep, dark silence of this surrounding, but he realizes that it's not his destination, because he needs to go miles and miles before sleep. With this confidence, we can fight with this pandemic and post-pandemic life.

Literature plays instructive roles too. It often shows us what to do and sometimes shows what not to do. This helps to reinforce our ability to think objectively. It shows the true picture in front of us and leaves it to us to make a decision. It helps man most when he is in oppress, pessimistic mood when he is not able to face the world around him. Even the religious texts, such as the 'Ramayana', 'Mahabharata', 'Bhagwat Geeta', 'Dnyaneshwari', tells us the meaning of life when we suffer and try to find the purpose of life. Literature plays an important role in sensitizing and informing people with intent and truth about any kind of misfortune, making them prepared for facing any disaster with reason and reality without resorting to outburst and emotions.

\section{CONCLUSION}

Literature plays a key role in crisis management. Therefore, we should get inspired and motivated by revisiting and rethinking literary books to fight against the moments of crises like Coronavirus. Literature has had a major impact on the development of society. It has shaped civilizations and nations. It plays an important role in transforming society and contributing significantly to the growth of nations.

Literature also helps people consider certain aspects of life when society gets trapped in a natural disaster or crisis. In particular, it inspires compassion and gives people a new perspective on their lives and the lives of others. Literature offers tips on how to tap and build your inner resilience. A resilient person looks for a silver liner in a crisis and move forward with a sense of hope for a better future. In such crises, the importance of individual and societal resilience is a must. And we need to do it all without falling apart and only literature can help you to achieve it. Literature has the power to uplift you, expose you to new ideas. That's something you need in these tense times. Reading literature during the period of crises encourages youin driving away isolation, retain sanity, fostering resilience, infusing empathy, and above all, instill the courage to face and hope. Sometimes a single line you read can stay with you for a long time to build resilience and inspire you during the toughtime of life.

\section{ACKNOWLEDGEMENT}

I whole-heartedly acknowledge all the sources and thankful to my friends, students and the teachers and students, who took the time to suggest me literary texts related to this paper and thanks are also due to authors / editors / publishers of all those sources.

\section{Source of Funding: None}

Conflict of Interest: The author declares no conflict of interest.

\section{REFERENCES}

1. WHO Director-General's opening remarks at the media briefing on COVID-19 - 11 March 2020. [Internet]. www.who.int. 2020. Available from: https://www.who.int/director-general/speeches/ detail

2. Responding to COVID-19 - Learnings from Kerala [Internet]. www.who.int. 2020. Available from: https://www.who.int/india/ news/feature-stories/detail/responding-to-covid-19---learningsfrom-kerala

3. Worldometer. Coronavirus toll update: Cases \& deaths by country [Internet]. Worldometers. 2021. Available from: https:// www.worldometers.info/coronavirus/

4. Ghosh A. How literature has helped us make sense of pandemics - Times of India [Internet]. The Times of India. 2020 [cited 2021 Dec 3]. Available from: https://timesofindia.indiatimes.com/ india/how-literature-has-helped-us-make-sense-of-pandemics/ articleshow/74841225.cms

5. Poe E. The Masque of the Red Death. [Internet]. The Public's Library and Digital Archive. 1942 [cited 2021 Dec 3]. Available from: http://www.ibiblio.org/.

6. Camus A. Albert Camus THE PLAGUE TRANSLATED FROM THE FRENCH BY Stuart Gilbert [Internet]. 1948. Available from: https://www.24grammata.com/wp-content/ uploads/2013/06/The_Plague_Albert_Camus-24grammata. com_.pdf

7. Edmond C. 5 books to read for context on the Coronavirus outbreak [Internet]. World Economic Forum. 2020 [cited 2021 Dec 3]. Available from: https://www.weforum.org/agenda/2020/03/ coronavirus-books-pandemic-reading-covid19

8. News ABC. George W. Bush in 2005: "If we wait for a pandemic to appear, it will be too late to prepare" [Internet]. ABC News. [cited 2020 Mar 5]. Available from: https://abcnews. go.com/Politics/george-bush-2005-wait-pandemic-late-prepare/ story? $\mathrm{id}=69979013$

9. Gates B. This Book Taught Me a Lot about the Spanish Flu [Internet]. gatesnotes.com. 2020. Available from: https://www. gatesnotes.com/Books/The-Great-Influenza 
10. Poetry Foundation. Poetry Foundation [Internet]. Poetry Foundation. 2015. Available from: https://www.poetryfoundation. org/poems/43290/the-second-coming
11. Poetry Foundation. Poetry Foundation [Internet]. Poetry Foundation. 2019. Available from: https://www.poetryfoundation. org/poems/45134/ode-to-the-west-wind 